\title{
Thromboelastometry - diagnostic examination method of clot formation in pigs subjected to experimental procedures of the left atrial appendage
}

\author{
Joanna Głodek $^{1^{*}}$ Zbigniew Adamiak $^{1}$ Jan Rogowski $^{2}$ Maciej Brzeziński ${ }^{2}$ Marek Jałyński $^{1}$ \\ Piotr Holak ${ }^{1}$ Yauheni Zhalniarovich ${ }^{1}$ Kamil Bury $^{2}$
}

${ }^{1}$ Department of Surgery and Radiology, Faculty of Veterinary Medicine, University of Warmia and Mazury in Olsztyn, Poland. E-mail: j_glodek@wp.pl. "Corresponding author.

${ }^{2}$ Department and Clinic of Cardiac and Vascular Surgery, Faculty of Medicine, Medical University of Gdańsk, Poland.

ABSTRACT: The aim of the study was to evaluate the usefulness of thromboelastometry in evaluations of the blood clotting system in pigs subjected to clip occlusion of the left atrial appendage. In this study, blood samples for thromboelastometry were collected, after clip occlusion of the left atrial appendage, from five pigs, in order to assess clot quality formation. Thromboelastometry with three ROTEM assays were performed: INTEM, EXTEM and FIBTEM. Results of the test were presented in TEMograms. The shape of the graph demonstrates hypercoagulability. In the thromboelastometry examination clot quality was stable in all animals.

Key words: ROTEM, hypercoagulability, TEMogram.

Tromboelastometria - método de análise de diagnóstico e formação de coágulos em suínos submetidos a procedimentos experimentais da aurícula atrial esquerda

RESUMO: O objetivo do estudo foi avaliar a estabilidade de formação de coágulos no tromboelastometria em suínos submetidos à oclusão grampo da aurícula esquerda. Neste estudo, as amostras de sangue foram recolhidas para tromboelastometria, após a oclusão grampo do apêndice atrial esquerdo, a partir de seis animais, a fim de avaliar a qualidade de formação de coágulo. Tromboelastometria com três ensaios foram realizados: INTEM, Extem e FIBTEM. Os resultados do teste foram apresentados em TEMograms. A forma do gráfico demonstra hipercoagulabilidade. Na qualidade de coágulos, o exame de tromboelastometria ficou estável em todos os animais.

Palavras-chave: formação de coágulos, porco, tromboelastometria.

Hemostasis and the physical properties of blood clots have to be closely monitored during and after surgery. Rotation thromboelastometry $\left(\mathrm{ROTEM}^{\circledR}\right)$ is one of the viscoelastic point-of- care (POC) haemostatic monitoring devices. Thromboelastometry is a diagnostic method for evaluating blood clotting and fibrinolysis rates. It supports rapid analyses of graphic and numeric data describing the blood clotting process. The main advantage of thromboelastometry is short time needed to perform procedure. It allows for real-time assessment of disturbances in coagulation process. According to GOGGS et al. (2010), thromboelastography is more useful for hemorrhage and thrombosis prediction than routine plasma-based assays. Thromboelastometry can be performed to distinguish the surgical bleeding from bleeding released by coagulation and fibrinolytic disorders. In veterinary medicine, clotting disorders are increasingly often diagnosed with the involvement of thromboelastometry and thromboelastography. For these reasons thromboelastometry can be successfully used to guide haemostatic therapy. Physical properties of blood clots need to be controlled in patients with critical injuries sustained in traffic accidents or falls from height. This diagnostic method can be also used in clinical practice in many medical disciplines like cardiothoracic surgery, obstetrics and critical care medicine. The objective of this study was to evaluate the usefulness of thromboelastometry in evaluations of the blood clotting system in pigs subjected to clip occlusion of the left atrial appendage.

The experiment was performed on five Polish Large White female pigs with body weight of $60 \mathrm{~kg}$. The animals were premedicated with atropine 
(Atropinum Sulfuricum) at $0.05 \mathrm{mg} \mathrm{kg}^{-1} \mathrm{BW}$ IM, and azaperone (Stresnil) at $2.5 \mathrm{mg} \mathrm{kg}^{-1} \mathrm{BW}$ IM. General anesthesia was induced with ketamine (Bioketan) at $8 \mathrm{mg} \mathrm{kg}^{-1}, \mathrm{BW}$, IM, and maintained with propofol (Scanofol) at $10 \mathrm{mg} \mathrm{BW}^{-1}$ IV. Additional butorphanol (Butomidor) was administered as the analgesic drug at $0.2 \mathrm{mg} \mathrm{kg}^{-1} \mathrm{BW}$ IV. Tracheal intubation with normo ventilation was performed. Ringer's lactate solution was administered during surgery. Blood samples were drawn from the marginal ear vein immediately after the surgery. Blood samples for ROTEM (Pentapharm) were collected in $3 \mathrm{~mL}$ tubes with $3.8 \%$ buffered sodium citrate solution. Three standard ROTEM assays were performed: intrinsic coagulation pathway - INTEM, extrinsic coagulation pathway - EXTEM, and functional fibrinogen - FIBTEM.

In one pig, INTEM, EXTEM and FIBTEM parameters could not be acquired due to technical problems. In the remaining patients, INTEM and EXTEM parameters, including CT (clotting time), CFT (clot formation time) and MCF (maximum clot firmness), as well as, FIBTEM parameter MCF, were presented in TEM grams. Maximum amplitude was noted in four pigs which were diagnosed with hypercoagulability. (Tables 1 and 2). In the generated TEMograms (Figures 1 and 2), clot quality was evaluated as stable based on reference values for ROTEM thromboelastometry porcine blood given by VELIK-SALCHNER et al. (2006). The shape of the graph demonstrated also high haemostatic potential.

In human cardiac surgery and cardiothoracic experiments in pigs the necessary components are: proper surgical procedures, rapid method for detection bleeding and hemorrhage and evaluation the stability of clot formation. Therefore, the aim of the study was to evaluate the usefulness of thromboelastometry for monitoring hemostasis and examination of the quality of clot formation in veterinary medicine. Routine clotting tests are time consuming, and they do not deliver sufficient information in the event of perioperative bleeding, blood clots and embolism. The results are often delayed and do not adequately reflect the patient's clinical condition (KOZEKLANGENECKER, 2010). Dynamic changes in the clotting system need to be carefully monitored to maximize the effectiveness of treatment in animals that sustained injuries of multiple organs or massive bleeding and during surgery. Thromboelastometry supports rapid and accurate evaluations of hemostatic processes, it contributes to mid operative and post operative diagnoses and can be effectively used to monitor changes in blood clotting and fibrinolysis (TRZEBICKI et al., 2009). Thromboelastometry and thromboelastography procedures are performed in pigs during scientific experiments (MOREY et al., 2010; SONDEEN et al., 2013; SPIEZIA et al., 2013; NATES et al., 2015). In the present study, thromboelastometry was carried out after clip occlusion of the left atrial appendage. Normal range values for porcine thromboelastography were described by VELIK-SALCHNER et al. (2006). A potential limitation of the cited study could be the young age (15-18 weeks) of the tested subjects, and the values given by the above authors could differ from the normal range for adult individuals. Authors suggested that swine blood present faster clotting

Table 1 - Experimental parameters CT- clotting time; CFT- clot formation time; MCF- maximum clot firmness, $\alpha$ - angle.

\begin{tabular}{llllll}
\hline Animal & & CT (s) & CFT (s) & MCF $(\mathrm{mm})$ & $\alpha\left({ }^{\circ}\right)$ \\
\hline \multirow{3}{*}{ Pig No 1 } & fibtem & 79 & & 100 & 85 \\
& intem & 81 & 94 & 100 & 84 \\
& extem & & 100 & 97 & 73 \\
Pig No 2 & & & 91 & 88 \\
& fibtem & 48 & 95 & 100 & 79 \\
& intem & 79 & 102 & 79 & 83 \\
Pig No 3 & extem & & & 83 & 86 \\
& fibtem & 51 & 14 & 95 & 83 \\
\hline
\end{tabular}

Ciência Rural, v.47, n.1, 2017. 
Table 2 - Statistical analysis of parameters, CT- clotting time; CFT- clot formation time; MCF- maximum clot firmness, $\alpha$ - angle; SD standard deviation.

\begin{tabular}{|c|c|c|c|c|c|c|c|c|}
\hline & mean CT (s) & $\pm \mathrm{SD} \mathrm{CT}(\mathrm{s})$ & $\begin{array}{c}\text { Mean CFT } \\
\text { (s) }\end{array}$ & $\begin{array}{c} \pm \text { SD CFT } \\
\text { (s) }\end{array}$ & $\begin{array}{c}\text { Mean MCF } \\
(\mathrm{mm})\end{array}$ & 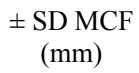 & mean $\left({ }^{\circ}\right)$ & $\pm \mathrm{SD} \alpha\left(^{\circ}\right)$ \\
\hline FIBTEM & & & & & 92.7592 .8 & 9.40 & & \\
\hline INTEM & 57.3 & 14.6 & 74.5 & 40.30 & 93.3 & 7.94 & 80.0 & 5.30 \\
\hline EXTEM & 72.0 & 18.1 & 94.0 & 13.4 & 96.5 & 7.0 & 84.8 & 2.20 \\
\hline
\end{tabular}

times than human blood tested in the same conditions. Guidelines for thromoboelastography in companion animals and horses were proposed by GOGGS et al. (2010). Their study is highly promising and advocates the use of thromboelastography in a broader range of clinical applications.

In our study, hypercoagulability, a condition that often affects pigs, was observed in all patients. International normalized ratio (INR) or abnormal prothrombin time (PT) can be affected by anticoagulant or pro coagulant and do not show real clinical state of hypercoagulopathy. Performed study testify that thromboelastometry was a quick diagnostic method for examination of the quality of the clot formation and also revealed that clot formation in pigs subjected to experimental procedures of the left atrial appendage was stable.

Thromboelastometry is a rapid and accurate method for monitoring hemostasis in surgical patients, and it is likely to become a diagnostic method of choice in veterinary cardiac surgery.

Animals used in this study were in accordance with the Polish of the Council of Animal Care standards and approved under the Institute for Animal Welfare and the Bioethics Committee (Protocol 04/2014D, 30.07.2014). All animals were

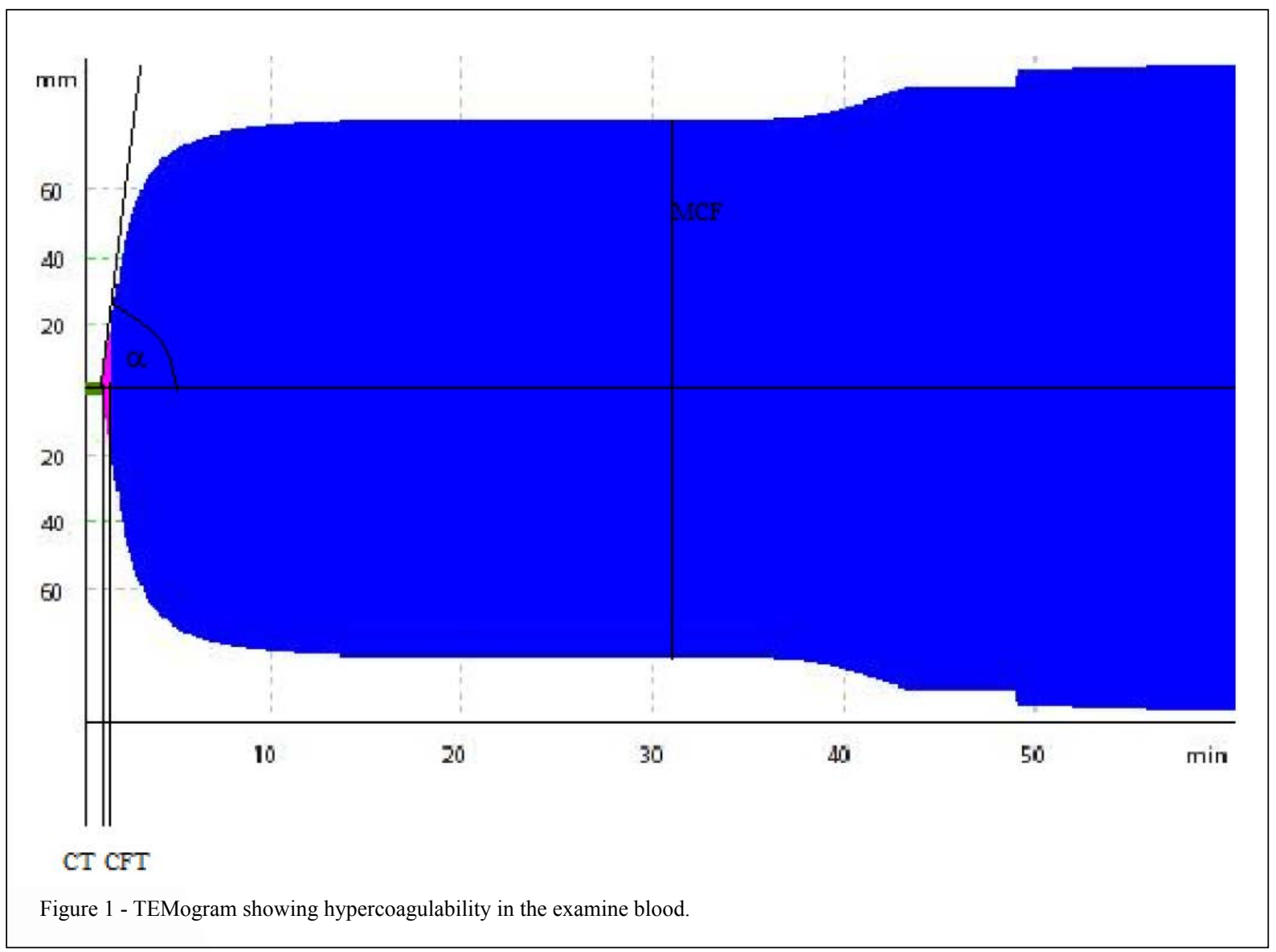

Ciência Rural, v.47, n.1, 2017. 


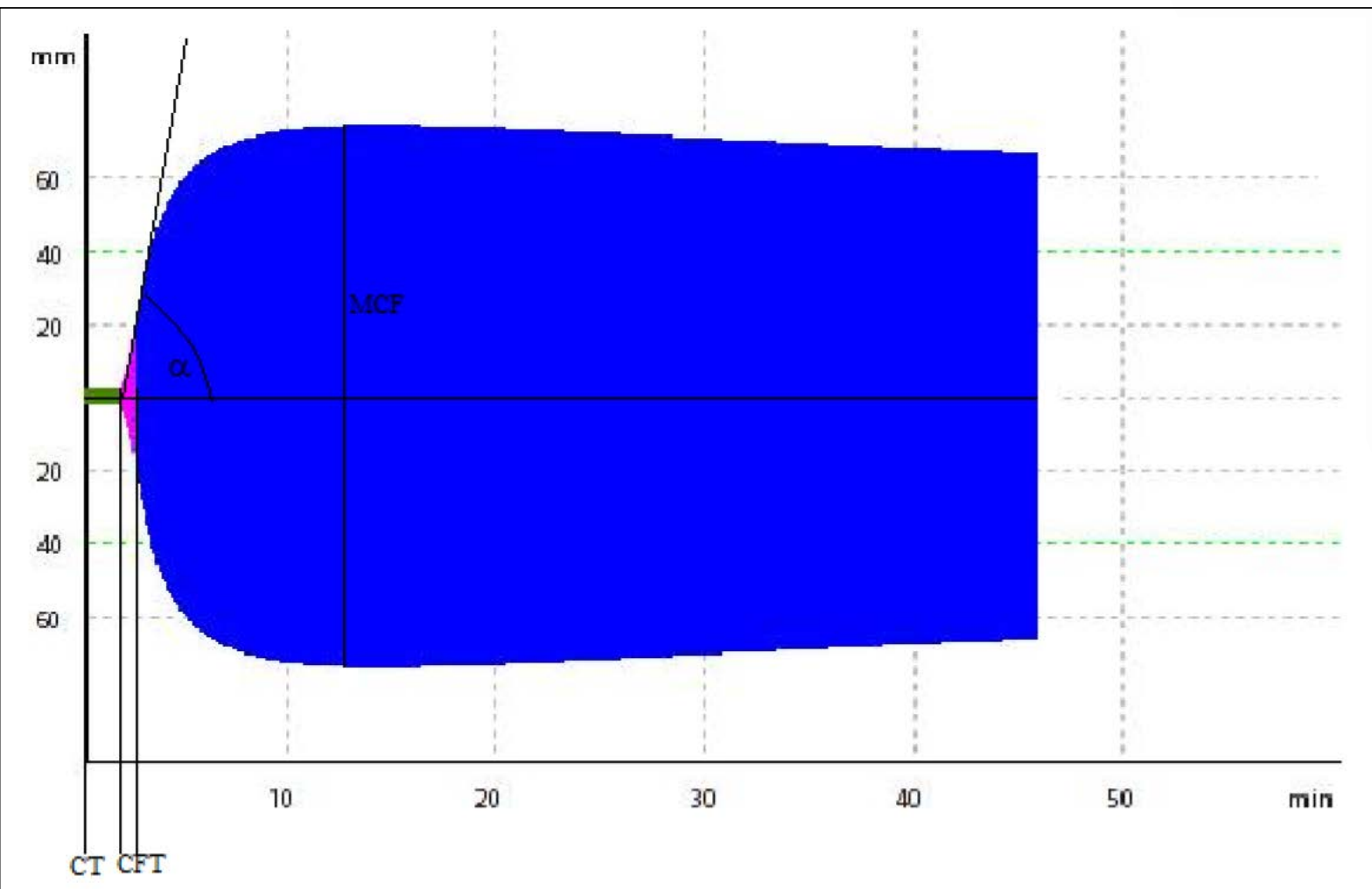

Figure 2 - TEMogram showing good strength of the fibrin clot.

handled humanely in compliance with the Policy on the Humane Care and Use of Laboratory Animals. Authors declare that there are no conflicts of interest.

\section{REFERENCES}

GOGGS, R. et al. Partnership on rotational visco Elastic test standardization (PROVETS): Evidence-based guidelines on rotational viscoelastic assays in veterinary medicine. Journal of Veterinary Emergency and Critical Care, v.24, n.1, p.1-22, 2014. Available from: $<$ http://onlinelibrary.wiley.com.wiley.han.uwm.edu.pl/doi/10.1111/ vec.12144/abstract>. Accessed: Mar. 31, 2016. doi: 10.1111/vec.12144.

KOZEK-LANGENECKER, S.A. Perioperative coagulation monitoring. Best Practice \& -Research Clinical Anaesthesiology, v.24, p.27-40, 2010. Available from: <http://www.sciencedirect. com/science/article/pii/S1521689609000731>. Accessed: Mar. 31, 2016. doi: 10.1016/j.bpa.2009.09.009.

MOREY, T.E. et al. Thromboelastographic and pharmacokinetic profiles of micro- and macro-emulsions of propofol in swine. Biopharmaceutics \& Drug Disposition, v.31, n.5-6, p.269-277, 2010. Available from: <http://onlinelibrary.wiley.com/doi/10.1002/ bdd. 709/abstract;jsessionid=7B650D5CD43DCA5344477CDBA3 CAFE17.f01t03>. Accessed: Mar. 31, 2016. doi: 10.1002/bdd.709.

NATES, J.L. et al. Study of acute hemocoagulation changes in a porcine endotoxemic shock model using thrombelastography.
Translational Research, The Journal of Laboratory and Clinical Medicine, v.165, n.5, p.549-557, 2015. Available from: <http:// www.sciencedirect.com/science/article/pii/S1931524414003089>. Accessed: Mar. 31, 2016. doi: 10.1016/j.trsl.2014.09.002.

SONDEEN, J.L. et al. Comparison between human and porcine thromboelastograph parameters in response to ex-vivo changes to plateles, plasma, and red blood cells. Blood Coagulation \& Fibrinolysis, v.24, n.8, p.818-829, 2013. Available from: <http:// journals.1ww.com/bloodcoagulation/Abstract/2013/12000/ Comparison_between_human_and_porcine.5.aspx $>$. Accessed: Mar. 31, 2016. doi: 10.1097/MBC.0b013e3283646600.

SPIEZIA, L. et al. Thromboelastogrphic evaluation of coagulative profiles in pig-to-monkey kidney xenotransplantation. Xenotransplantation, v.20, n.2, p.89-99, 2013. Available from: $<$ http://onlinelibrary.wiley.com/doi/10.1111/xen.12024/abstract>. Accessed: Mar. 31, 2016. doi: 10.1111/xen.12024.

TRZEBICKI, J. et al. Thromboelastometry- a new method supporting the therapeutical decisions in the coagulopathy based on the Hartet's thromboelastography. Polski Merkuriusz Lekarski, v.158, p.85-91, 2009. Available from: <http://polmerklek.pl>. Accessed: Mar. 31, 2016. PMID:19856870.

VELIK-SALCHNER, C. et al. Normal values for thrombelastography (ROTEM) and selected coagulation parameters in porcine blood. Thrombosis Research, v.117, n.4, p.597-602, 2006. Available from: <http://www.sciencedirect.com/science/article/pii/ S0049384805002434>. Accessed: Mar. 31, 2016. doi: 10.1016/j. thromres.2005.05.015. 